УДК 616.314-018.4-089.873-089.843].001.36

DOI 10.11603/2311-9624.2021.2.12327

\author{
(А. Іде ${ }^{1}$, С. Іде ${ }^{1}$, Я. Е. Варес ${ }^{1,2}$, Я. Я. Варес ${ }^{2}$ \\ Міжнародний фонд імплантологів, м. Мюнхен, Німеччина ${ }^{1}$ \\ Львівський національний медичний університет імені Данила Галицького 2 \\ e-mail: vares-dent@ukr.net
}

\title{
Обгрунтування доцільності кісткової редукції у технології «Стратегічна імплантація»
}

\section{ІНФОРМАЦІЯ}

Надійшла до редакції/Received: 05.12.2020 p.

Ключові слова: кортико-базальна імплантація; стратегічна імплантація; кісткова редукція; негайне функціональне навантаження.

\section{АНОТАЦІЯ}

Резюме. Використання технології «Стратегічна імплантація» дозволяє виконувати тотальне протезування щелеп на зубних імплантатах навіть в умовах критично зменшеного об’єму кісткової тканини у протоколі негайного навантаження. Проте для реалізації вищенаведеної концепції варто чітко дотримуватись встановлених правил протезування на кортикобазальних імплантатах, зокрема розміщення зубних дуг у стандартних позиціях і під стандартним кутом до протетичних площин, повної симетрії для досягнення двостороннього жування та уникнення жувального перевантаження тощо, що у багатьох випадках пов'язано з необхідністю редукції кісткової тканини альвеолярного відростка в тому чи іншому ступені.

Мета дослідження - детально описати як технологія «Стратегічна імплантація» дозволяє в межах одного хірургічного втручання, включно із видаленням зубів, редукцією кісткової тканини та встановленням імплантатів, провести повну реконструкцію щелеп на прикладі клінічного випадку з критичною асиметрією зубоальвеолярного комплексу.

Матеріали і методи. Обстежено та оперовано пацієнтку 53 років із частковою відсутністю зубів на обох щелепах та наявністю значного зубоальвеолярного видовження. Лікування полягало у множинному видаленні зубів, редукції альвеолярних відростків, встановленні кортико-базальних імплантатів 3 їх негайним навантаженням упродовж 3 днів.

Результати дослідження та їх обговорення. Як видно з наведеного клінічного прикладу, редукція кісткової тканини в комплексній хірургічно-ортопедичній реабілітації пацієнтки дозволила не лише змістити верхні фронтальні зуби краніальніше і замаскувати перехідну зону між протезною конструкцією та власними яснами, що було доцільним з точки зору естетики, але й забезпечити однакові передньо-задні площини прикусу за Іде з обох боків, що сприяло оптимізації функції жування.

Висновки. Кортико-базальна імплантація, зокрема у вигляді технології «Стратегічна імплантація», звільняє імплантологію від потреби у великому об’ємі кісткової тканини, особливо у вертикальному напрямку, що нівелює проблему кісткової аугментації, а в поєднанні з редукцією кісткової тканини дозволяє досягнути відмінних довготермінових естетичних і функціональних результатів, відкриваючи двері для абсолютно нового, спрощеного та доступного відновлення адекватного стоматологічного статусу пацієнтів, незалежно від наявного об’єму кісткової тканини, їі якості, стану існуючих зубів тощо. 
Вступ. У традиційній двоетапній зубній імплантації методику кісткової редукції застосовують доволі рідко. Єдиними показаннями до редукції є корекція міжальвеолярної висоти або досягнення необхідної ширини кісткового ложа для встановлення імплантатів у пацієнтів із «лезоподібним» альвеолярним відростком [3, 9-11]. Частіше, навпаки, виникає потреба в застосуванні кісткової аугментації, оскільки двоетапні/двокомпонентні імплантати великого діаметра вимагають наявності достатнього об’єму кісткової тканини для їх встановлення.

Натомість одноетапні/однокомпонентні імплантати, які складаються 3 ендосальної частини, абатмента і трансмукозної шийкової зони і є доступними у вигляді конструкцій для кортико-базальної та компресійної імплантації, потребують значно меншого вертикального та горизонтального об'єму кісткової тканини порівняно з двокомпонентними конструкціями. Кортико-базальні одноетапні імплантати вимагають 5 мм (а в деяких випадках навіть менше) кісткової тканини у вертикальному напрямку і при цьому можуть бути використані у протоколі негайного навантаження. Більше того, їх конструкція не вимагає наявності губчастої кісткової тканини, оскільки фіксація імплантатів здійснюється в кортикальних (щічних, язикових/піднебінних) пластинках щелеп [5]. Навіть у випадках екстремально атрофованих або «лезоподібних» альвеолярних відростках ці імплантати можливо встановити на обох щелепах згідно 3 протоколом негайного функціонального навантаження, використовуючи спеціальну технологію, запатентовану під назвою «Стратегічна імплантація» (Strategic implant) [1]. Водночас, для покращення естетичного та функціонального результату, особливо у випадках зубоальвеолярного видовження, «ясенної» посмішки, асиметрії жувальної площини тощо, технологія «Стратегічна імплантація» передбачає значну редукцію надлишкової альвеолярної кістки [2].

Метою дослідження було детально описати як технологія «Стратегічна імплантація» дозволяє в межах одного хірургічного втручання, включно з видаленням зубів, редукцією кісткової тканини та встановленням імплантатів, провести повну реконструкцію щелеп на прикладі клінічного випадку з критичною асиметрією зубоальвеолярного комплексу.
Матеріали і методи. Пацієнтка 53 років, яка не курить та дотримується здорового способу життя, звернулася у стоматологічну установу зі скаргами на відсутність окремих зубів верхньої та нижньої щелеп, неможливість адекватного жування, естетичний недолік у вигляді надмірної видимості зубів і ясен верхньої щелепи в спокої та під час посмішки та проханням повної реставрації обох щелеп фіксованими протезними конструкціями з опорою на зубні імплантати. Під час клінічного огляду констатовано наявність протрузії фронтальних зубів верхньої щелепи, «ясенної» посмішки, ознаки багаторазового консервативного лікування наявних зубів (множинний вторинний карієс, пломби, ендодонтично ліковані зуби, множинна дисколорація зубів, металокерамічні коронки тощо), незадовільний гігієнічний стан ротової порожнини (рис. 1). У 2-му квадранті виявлено елонгацію зубів 25; 26; 27 з наявністю ясенних рецесій із вестибулярного боку (рис. 2). У 4-му квадранті виявлено, що зуб 47 при жуванні торкається слизової оболонки альвеолярного відростка верхньої щелепи (за типом феномену Попова - Годона) (рис. 3).

Рентгенологічного констатовано наявність кісткової деструкції у проекції коренів 22; 35; 34; 47; 48 зубів, зубоальвеолярного видовження у 2-му та 4-му квадрантах (рис. 4). Рекомендований план лікування передбачав видалення усіх зубів, редукцію кісткової тканини в 2-му та 4-му квадрантах та у фронтальному відділі верхньої щелепи з метою забезпечення задовільного естетичного результату та вирівню-

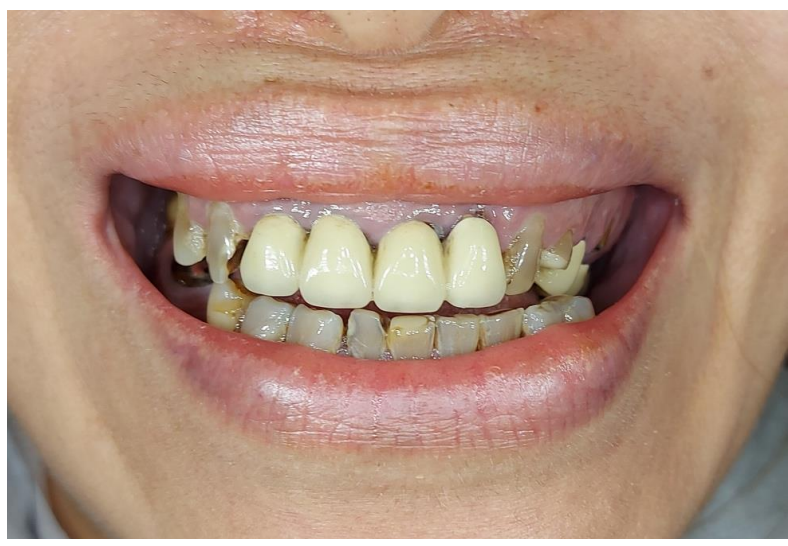

Рис. 1. Клінічне фото пацієнтки Г., 53 р., на момент звертання. Протрузія верхніх фронтальних зубів. «Ясенна» посмішка. Критичні ушкодження зубів, що багаторазово зазнавали консервативного лікування. Незадовільний гігієнічний стан ротової порожнини. 


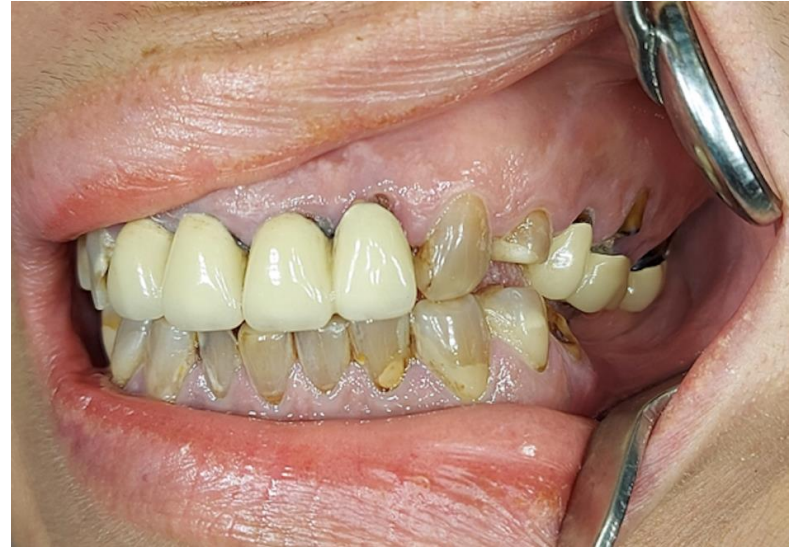

Рис. 2. Клінічне фото зубного ряду в 2-му квадранті. Елонгація зубів 25; 26; 27. Наявність ясенних рецесій із вестибулярного боку.

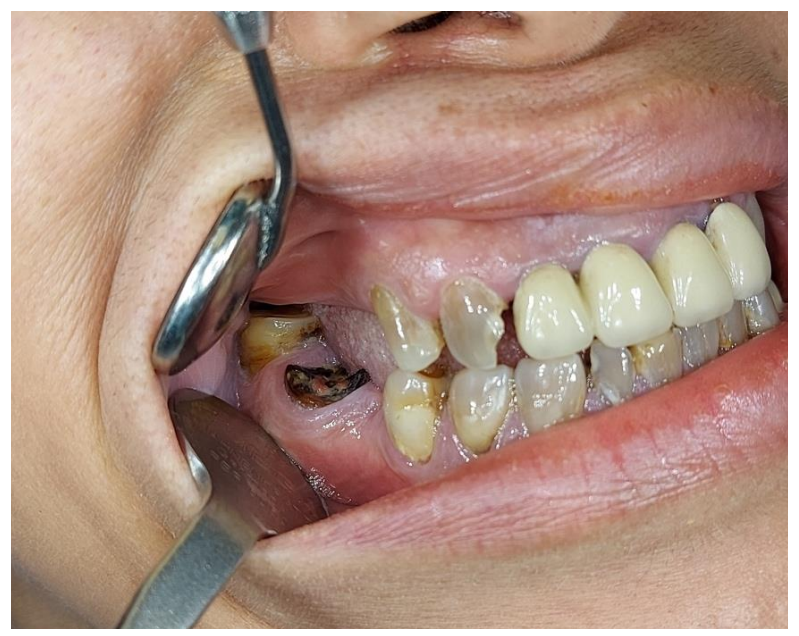

Рис. 3. Клінічне фото зубного ряду в 4-му квадранті. Зуб 48 при при жуванні торкається слизової оболонки альвеолярного відростка верхньої щелепи.

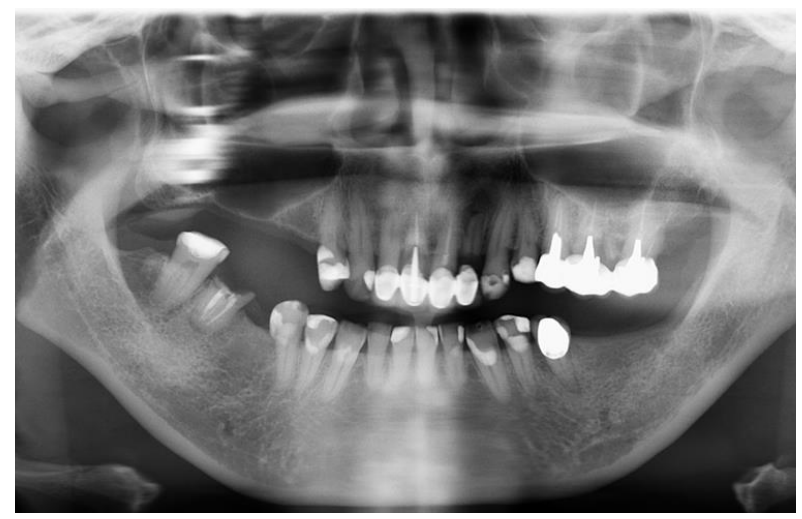

Рис. 4. Ортопантомограма пацієнтки Г., 53 р., на момент звертання. Наявність деструкції кісткової тканини в проекції коренів 22; 35; 34;

47; 48 зубів. Значне зубоальвеолярне видовження у 2-му та 4-му квадрантах. вання жувальних площин (передньо-задніх площин прикусу за Іде) по обидва боки щелепи. Після роз'яснення пацієнтці альтернативних варіантів реабілітації та отримання письмової інформованої згоди на запропонований варіант лікування під місцевою анестезією 3 седацією було проведено видалення зубів 14; $13 ; 12 ; 11 ; 21 ; 22 ; 23 ; 24 ; 25 ; 26 ; 27 ; 35 ; 34 ; 33 ; 32 ; 31$; $41 ; 42 ; 43 ; 44 ; 45 ; 47 ; 48$, редукцію кісткової тканини у фронтальному відділі верхньої щелепи та у проекції молярів у 2-му та 4-му квадрантах за допомогою кісткових кусачок та фрез, встановлення 21 кортико-базального імплантату (3 них 18 - BCS та 3 TPG Uno (Ihde Dental AG, Швейцарія)), ушивання рани та отримання відбитків із реєстрацією прикусу за оригінальною авторською методикою [8].

Пізніше у той же день проведено примірку воскових композицій майбутніх протезних конструкцій та необхідні корекції. У зуботехнічній лабораторії виготовлено 2 циркулярні мостоподібні конструкції за цифровою технологією Exосаd фрезеровані з дисків ISO-Fusion (Simpladent GmbH, Швейцарія). Рожеве колорування штучних ясен проведено 3 використанням твердого та рідкого композиту «Estheticum» (Simpladent GmbH, Швейцарія).

На наступний день, після виконання усіх необхідних корекцій, обидві мостоподібні конструкції було встановлено без цементу, з метою забезпечення кращого загоєння м’яких тканин. Зняття швів та цементування з використанням цементу Fuji plus (GC, Японія) було виконано через день. Оклюзійні співвідношення контролювали упродовж наступних двох днів, для подальшого контролю пацієнта попросили з'явитися через три місяці. Результати лікування продемонстровано на рисунках 5, 6.

Результати досліджень та їх обговорення. Упродовж життя, з багатьох причин, зуби мають тенденцію до елонгації, що може призводити до незадовільної естетичної та функціональної ситуації. У такому випадку зовнішній вигляд пацієнта як із закритим ротом, так і під час посмішки, буде змінюватись. Якщо ж зуби в дистальних відділах щелеп зазнають елонгації, змінюється площина прикусу. Разом з тим, як зуби, що не мають антагоністів, зазнають елонгації, зуби, що знаходились в оклюзії, виходитимуть $з$ неї. В описаному клінічному випадку площини прикусу з правого та лівого боків суттєво відрізнялись. Це означає, що 


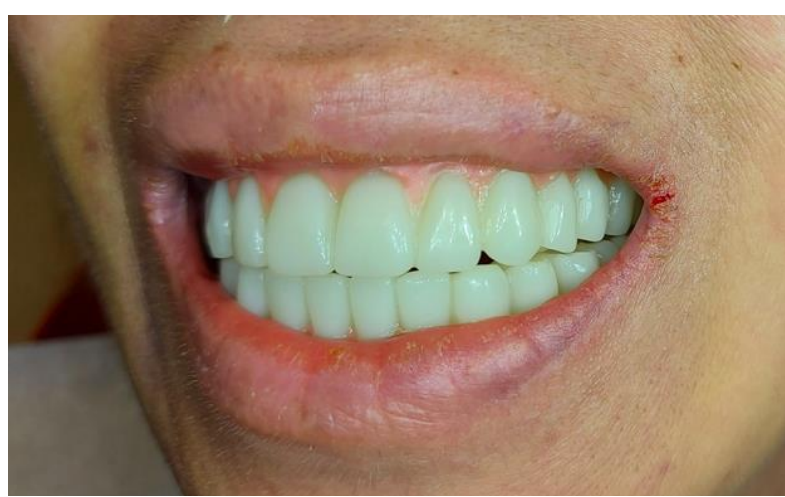

Рис. 5. Клінічне фото пацієнтки Г., 53 р., 3 фіксованими протезними конструкціями на 3 день після імплантації. Досягнення правильного прикусу та симетричних жувальних площин. Без застосування кісткової редукції неможливо було б досягти задовільного естетичного результату, оскільки перехідна зона між протезною конструкцією та яснами пацієнтки була б помітною.

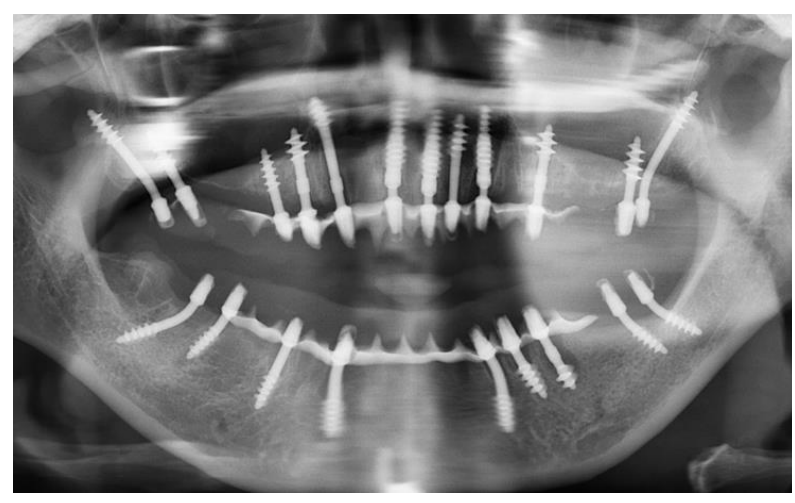

Рис. 6. Ортопантомограма пацієнтки Г., 53 р., на 3 день після імплантації. Порівняно 3 рисунком 4, видно, що було редуковано великий об'єм кісткової тканини в 2-му та 4-му квадранті. Усі імплантати встановлені бікортикально.

без кісткової редукції досягти однакових передньо-задніх площин прикусу за Іде було б неможливо. Передньозадні площини прикусу за Іде (Anterior-posterior planes of bite of Ihde, APPI) - найважливіший критерій для визначення можливості лікування пацієнта за протоколом негайного навантаження, який був запропонований у 2020 р. [6], та включає зміни у вертикальному положенні зубів, а також зміни площини прикусу, створені нахилом зубів, i, по суті, замінює необхідність встановлення "нормальної» кривої Шпеє. Лікування за технологією «Стратегічна імплантація» у протоколі негайного навантаження не рекомендується, якщо передньозадні площини прикусу за Іде з обох боків неможливо вирівняти [6, 7]. Отже, в наведеному клінічному випадку потреба в редук- ції кісткової тканини була обгрунтована, як мінімум, двома причинами. По-перше, висота альвеолярного відростка у фронтальному відділі верхньої щелепи була зменшена для того, щоб змістити верхні фронтальні зуби краніальніше і замаскувати перехідну зону між протезною конструкцією та власними яснами пацієнта. Таким чином, вищезгадана зона залишатиметься невидимою незалежно від рухів верхньої губи та мімічних м'язів і забезпечуватиметься задовільний естетичний результат. По-друге, редукція кісткової тканини в 2-му та 4-му квадрантах дозолила забезпечити однакові передньо-задні площини прикусу за Іде з обох боків.

Редукція кісткової тканини перед встановленням імплантатів має ще низку додаткових переваг. Так, вертикальна редукція дозволяє розташувати імплантати в більш глибоких (базальних) шарах кісткової тканини щелеп, які є більш стабільними та здатними до функціонального навантаження. Тим самим досягається стабільність лінії слизової оболонки, і попередження природної післяектракційної атрофії альвеолярного відростка, а утворення проміжків між слизовою оболонкою та мостоподібною конструкцією може бути обмежене або принаймні контрольоване до певної міри. Це забезпечує хорошу функцію мовлення і дозволяє уникнути потрапляння їжі під мостоподібні конструкції. Більше того, позитивним аспектом редукції $є$ той факт, що кортикальна кістка, яка залишається після редукції, стає міцнішою, що сприяє кращій фіксації кортико-базальних імплантатів. Вказаний феномен пояснюють фундаментальні дослідження J. Wolff [12], який ще наприкінці XIX сторіччя сформулював основні принципи функціонування кісткової тканини у вигляді простих для розуміння правил:

- кістка самостійно вирівнює свою внутрішню структуру та зовнішню морфологію, щоб оптимально розподіляти навантаження;

- кістка регулює власний об'єм таким чином, що він оптимізується 3 урахуванням функціональних потреб. Це означає, що в клінічній реальності, коли відбувається повторне ремоделювання (при незмінному функціональному попиті), кістка щоразу матиме менший об’єм. Оскільки ремоделювання відбувається, як правило, у дорослому віці, а гормональне тло в цей період життя не сприяє 
подальшому росту кістки, кістковий об’єм буде постійно зменшуватися, відбуватиметься атрофія;

- разом з тим, кісткова тканина збільшує свою мінералізацію, а отже, міцність відповідно до функціональної потреби;

- отже, якість та міцність кістки зростатиме, якщо іï об’єм є недостатнім для забезпечення функціональних навантажень.

Дещо пізніше ці явища були описані A. E. Goodship et al. [4] як «оптимізація кісткової тканини».

Висновки. У традиційній імплантології (3 використанням двоетапних/двокомпонентних імплантатів) близько 50 \% пацієнтів 3 тих чи інших причин потребують кісткової аугментації - процедури часто незрозумілої для пацієнта. Натомість, кортико-базальна імплантація, зокрема у вигляді технології «Стратегічна імплантація" звільняє імплантологію від потреби у великому об’ємі кісткової тканини, особливо у вертикальному напрямку, що нівелює проблему кісткової аугментації, а в поєднанні з редукцією кісткової тканини дозволяє досягти відмінних довготермінових естетичних і функціональних результатів, відкриваючи двері для абсолютно нового, спрощеного та доступного відновлення адекватного стоматологічного статусу пацієнтів, незалежно від наявного об’єму кісткової тканини, їі якості, стану існуючих зубів тощо.

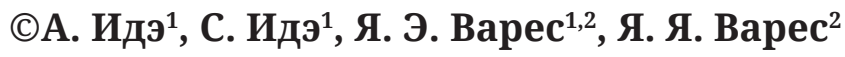

Международный фонд имплантологов, г. Мюнхен, Германия ${ }^{1}$

Львовский национальный медицинский университет имени Данила Галицкого 2

\section{Обоснование целесообразности костной редукции в технологии «Стратегическая имплантация"}

Резюме. Использование технологии «Стратегическая имплантация» позволяет проводить тотальное протезирование челюстей на зубных имплантатах даже в условиях критически малого объема костной ткани в протоколе немедленной нагрузки. В то же время, для реализации приведенной выше концепции следует четко придерживаться установленных правил протезирования на кортико-базальных имплантатах, а именно размещения зубных дуг в стандартных позициях и под стандартным углом к протетическим плоскостям, полной симметрии для достижения двухстороннего жевания и предотвращения жевательной перегрузки и т.п., что во многих случаях связано с необходимостью редукции костной ткани альвеолярного отростка в той или иной мере.

Цель исследования - подробно описать как технология «Стратегическая имплантация» позволяет в рамках одного хирургического вмешательства, включая удаление зубов, редукцию костной ткани и установку имплантатов, провести полную реконструкцию челюстей на примере клинического случая с критической асимметрией зубоальвеолярного комплекса.

Материалы и методы. Обследовано и оперировано пациентку 53 лет с частичным отсутствием зубов на обеих челюстях и наличием значительного зубоальвеолярного удлинения. Лечение состояло в множественном удалении зубов, редукции альвеолярных отростков, установке кортико-базальных имплантатов с их немедленной нагрузкой в течении 3 дней.

Результаты исследований и их обсуждение. Как следует из приведенного клинического примера, редукция костной ткани в комплексной хирургично-ортопедической реабилитации пациентки позволила не только сместить верхние фронтальные зубы краниальнее и замаскировать переходную зону между протезной конструкцией и собственными деснами, что было уместным с точки зрения эстетики, но и обеспечить одинаковые передне-задние плоскости прикуса по Идэ с обеих сторон, что способствовало оптимизации жевательной функции.

Выводы. Кортико-базальная имплантация, в том числе в виде технологии «Стратегическая имплантация» освобождает имплантологию от потребности в большом объеме костной ткани, особенно в вертикальном направлении, что нивелирует проблему костной аугментации, а в сочетании с редукцией костной ткани позволяет достигать отличных долгосрочных эстетических и функциональных результатов, открывая дверь для абсолютно нового, упрощенного и доступного восстановления адекватного стоматологического статуса пациентов, независимо от существующего объема костной ткани, ее качества, состояния зубов и т.п.

Ключевые слова: кортико-базальная имплантация; стратегическая имплантация; костная редукция; немедленная функциональная нагрузка. 


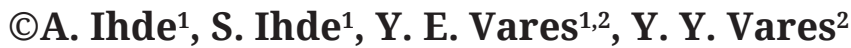 \\ International Implant Foundation, Munich, Germany ${ }^{1}$ \\ Danylo Halytsky Lviv National Medical University ${ }^{2}$
}

\title{
Substantiation of the expediency of bone reduction in Strategic Implant ${ }^{\circledR}$ technology
}

Summary. The use of Strategic Implant technology allows to perform total reconstruction of the jaws on dental implants, even in conditions of critically reduced bone volume in the protocol of immediate loading. However, to implement the aforementioned concept, it is necessary to strictly follow the established rules of prosthetics on cortico-basal implants, including placement of dental arches in standard positions and at a standard angle to prosthetic planes, complete symmetry to achieve bilateral chewing and avoid chewing overload, etc. which is frequently associated with the need to reduce the bone tissue of the alveolar process to some extent.

The aim of the study - to describe how Strategic implant technology allows for a complete reconstruction of the jaws in a single surgical procedure, including tooth extraction, bone reduction and implant placement, on the example of a clinical case of a patient with critical asymmetry of the dento-alveolar complex.

Materials and Methods. A 53-year-old patient with partial edentulism on both jaws and the presence of significant dento-alveolar elongation was examined and operated on. Treatment consisted of multiple tooth extraction, reduction of alveolar processes, installation of cortico-basal implants with their immediate loading within 3 days.

Results and Discussion. As can be seen from the clinical example, the reduction of bone tissue as a measure of surgical and зкщиеруешс rehabilitation of the patient allowed not only to move the upper front teeth more cranially and mask the transition zone between the prosthetic structure and the patient's own gums, which was appropriate from an aesthetic point of view, but also to align anterior-posterior planes of Ihde on both sides, which contributed to the optimization of chewing.

Conclusions. Cortico-basal implantation, in particular in the form of Strategic Implant technology frees implantology from the need for a large volume of bone tissue, especially in the vertical direction, which eliminates the problem of bone augmentation, and in combination with bone reduction allows to achieve excellent long-term aesthetic and functional results , opening the door for a completely new, simplified and affordable restoration of adequate dental status of patients, regardless of the available volume of bone tissue, its quality, the condition of existing teeth, etc.

Key words: cortico-basal implantation; Strategic Implant; bone reduction; immediate functional loading.

\section{СПИСОК ЛІТЕРАТУРИ}

1. Іде С. Введення у роботу із Стратегічними імплантатами $^{\circledR}$ / С. Іде, Я. Е. Варес, А. Іде. - Мюнхен : International Implant Foundation Publishing, 2015. - 82 p.

2. Ефективність диференційованого лікування хворих із вертикальною диспропорцією середньої третини обличчя / А. Іде, А. Чакранараян, О. Сіпіч [та ін.] // Львівський клінічний вісник. - 2020. - № 2 (30). - С. 21-28.

3. Virtually guided alveolar ridge reduction combined with computer-aided implant placement for a bimaxillary implant-supported rehabilitation: A clinical report / M. Beretta, P. P. Poli, S. Tansella, C. Maiorana // J. Prosthet. Dent. - 2018. - Vol. 120 (2). - P. 168-172.

4. Goodship A. E. Functional adaptation of bone to increased stress. An experimental study / A. E. Goodship, L. E. Lanyon, H. McFie // J. Bone Joint Surg. Am. - 1979. Vol. 61 (4). - P. 539-546.

5. New systematic terminology of cortical bone areas for osseo-fixated implants in strategic oral implantology / S. Ihde, A. Ihde, V. Lysenko, [et al.] // J. J. Anatomy. 2016. - Vol. 1 (2). - P. 007.

6. Ihde S. Cookbook Mastication / S. Ihde, A. Ihde. -4 th Edn. - International Implant Foundation Publishing, Munich, Germany, 2020.
7. Restoring the correct sagittal and vertical inter-maxillary relationship in skeletal Class 2 cases: The technology of the Strategic Implant ${ }^{\circledR}$ offers the possibility of creating harmonic function even in cases with severe skeletal discrepancies / S. Ihde, A. Ihde, V. Gaur [et al.] // J. CranioMaxillofacial implants Dir. - 2018. - Vol. 13. - P. 3-15.

8. Ihde A. A novel approach to bite on implants for use in immediate loading protocols: the split bite procedure / A. Ihde // J. Cranio-Maxillofacial implants Dir. - 2020. Vol. 14. - P. 175-183.

9. Massoumi N. S. Guided Bone Reduction to Facilitate Immediate Implant Placement Using CAD/CAM Surgical Guides After Full-Mouth Extractions / N. S. Massoumi // J. Oral \& Maxillofac. Surg. - 2016. - Vol. 74 (9). - P. 32-33. 10. Nejad M. F. Combining guided alveolar ridge reduction and guided implant placement for all-on-4 surgery: A clinical report / M. F. Nejad, P. Proussaefs, J. Lozada // J. Prosthetic Dent. - 2020. - Vol. 115 (6). - P. 662-667.

11. Turkyilmaz I. Use of reciprocating saw for alveolar ridge reduction in the anterior mandible for immediate load implant-supported hybrid dentures / I. Turkyilmaz // J. Oral Maxillofac Surg. - 2010. - Vol. 68 (6). - P. 1334-1337. 12. Wolff J. Das gesetz der transformation der knochen / J. Wollf // Verlag Aug. V Hirschwald, Berlin, Germany, 1892. 


\section{REFERENCES}

1. Ihde, S., Vares, Ya., \& Ihde, A. (2015). Vvedennia u robotu iz Stratehichnymy implantamy ${ }^{\circledR}$ [Introduction to Strategic implants ${ }^{\circledR}$. Munich: International Implant Foundation Publishing [in Ukrainian].

2. Ihde, A., Chakranarayan, A., Sipic, O., Soni, P., Ihde, S., \& Vares, Ya.E. (2020). Efectyvnist dyferenciiovanoho likuvannia khvorykh iz vertykalnoiu dysproportsiieiu serednioi tretyny oblychchia [Effectiveness of differential treatment of patients with vertical maxillary excess]. Lviv Clin. Bull, 2 (30), 21-28 [in Ukrainian].

3. Beretta, M., Poli, P.P., Tansella, S., \& Maiorana, C. (2018). Virtually guided alveolar ridge reduction combined with computer-aided implant placement for a bimaxillary implant-supported rehabilitation: A clinical report. J. Prosthet. Dent.,120 (2), 168-172.

4. Goodship, A.E., Lanyon, L.E., \& McFie, H. (1979). Functional adaptation of bone to increased stress. An experimental study. J. Bone Joint Surg. Am., 61 (4), 539546.

5. Ihde, S., Ihde, A., Lysenko, V., Konstantinovic, V., \& Palka, L. (2016). New systematic terminology of cortical bone areas for osseo-fixated implants in strategic oral implantology. J. J. Anatomy, 1 (2), 007.

6. Ihde, S., \& Ihde, A. (2020). Cookbook Mastication. 4th Edn. International Implant Foundation Publishing, Munich, Germany.
7. Ihde, S., Ihde, A., Gaur, V., Lysenko, V., \& Palka, L. (2018). Restoring the correct sagittal and vertical inter-maxillary relationship in skeletal Class 2 cases: The technology of the Strategic Implant ${ }^{\circledR}$ offers the possibility of creating harmonic function even in cases with severe skeletal discrepancies. J. CranioMaxillofacial Implants Dir., 13, 3-15.

8. Ihde, A. (2020). A novel approach to bite on implants for use in immediate loading protocols: the split-bite procedure. J. Cranio-Maxillofacial Implants Dir., 14, 175183.

9. Massoumi, N.S. (2016). Guided Bone Reduction to Facilitate Immediate Implant Placement Using CAD/ CAM Surgical Guides After Full-Mouth Extractions. J. Oral Maxillofac Surg., 74 (9), 32-33.

10. Nejad, M.F., Proussaefs, P., Lozada, J. (2020) Combining guided alveolar ridge reduction and guided implant placement for all-on-4 surgery: A clinical report. J. Prosthetic Dent., 115 (6), 662-667.

11. Turkyilmaz, I. (2010). Use of reciprocating saw for alveolar ridge reduction in the anterior mandible for immediate load implant-supported hybrid dentures. J. Oral Maxillofac Surg., 68 (6), 1334-1337.

12. Wolff, J. (1892). Das gesetz der transformation der knochen. Verlag Aug. V Hirschwald, Berlin, Germany. 